\title{
Klippel-Trenaunay syndrome associated to squamous cell carcinoma: a safe choice
}

\author{
Massimo Mattioli 지, ${ }^{1}$ Gabriele Pagliariccio (다, ${ }^{2}$ Luciano Carbonari ${ }^{2}$
}

${ }^{1}$ UOC Pronto Soccorso e Medicina d'Urgenza, Azienda Ospedaliera Ospedali Riuniti Marche Nord, Pesaro, Italy ${ }^{2} \mathrm{SOD}$ Chirurgia Vascolare, Azienda Ospedaliero Universitaria Ospedali Riuniti di Ancona Umberto I G M Lancisi G Salesi, Ancona, Italy

\section{Correspondence to} Dr Massimo Mattioli; mattio87@libero.it

Accepted 27 January 2021

\section{DESCRIPTION}

A 75-year-old patient was admitted to the emergency department for recurrent and significant bleedings through an indolent ulcer of the medial region of the right knee. The cutaneous lesion appeared 4 months before and was still growing in dimension, without signs of healing. Physical examination also revealed hypertrophy of the whole leg, compared with the opposite, with regular throbs on palpation. The CT angiography showed a dense network of arteriovenous fistulas involving the whole lower limb, especially below the wound (figure 1). A clinical diagnosis of Klippel-Trenaunay syndrome (KTS) was made, and the skin biopsy confirmed the suspicion of squamous cell carcinoma; unfortunately, the analysis of PIK3CA gene was not available.

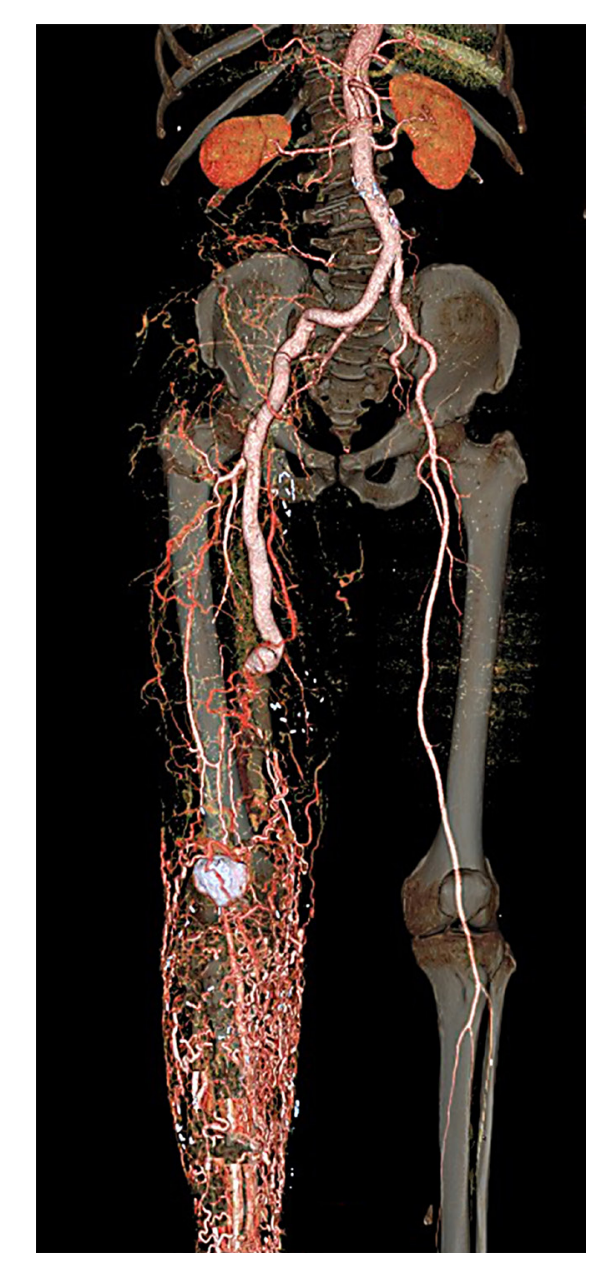

Figure 1 CT angiography reconstruction of the lower limbs showing the wide extension of the abnormal vascularisation.

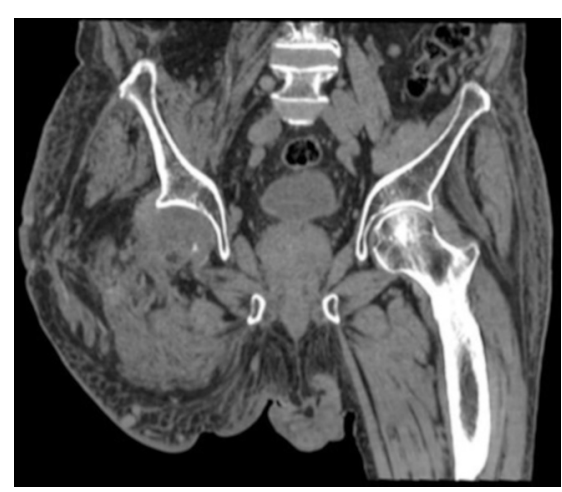

Figure 2 Post-operative CT of the hip.

After a multidisciplinary consensus (orthopaedic, vascular surgeon, interventional radiologist, dermatologist), considering the high risk of intraoperative major bleeding and the associated cancer, lower limb amputation was purposed. The patient underwent surgery: the right lower limb was amputated by hip disarticulation with surgical ligation of the external right iliac artery, without complications (figure 2). After a 2-year follow-up he was still well.

KTS occurs as a result of somatic mutations in the PIK3CA gene, resulting in vascular malformation that commonly involves lower limbs. ${ }^{12}$ The age, the clinical presentation, the localization and the associated conditions should guide in the management. Ishikawa $e t \mathrm{al}^{3}$ reported a good long-term outcome after a conservative treatment of KTS in a 1-year-old child, who developed a squamous cell carcinoma in the affected leg at the age of 37. Conversely, in our old patient, the management of two conditions and the concomitant bleeding risk required a demolitive approach accepting the reduction in quoad valetudinem prognosis. To date, no previous reports are present in literature; therefore, this surgical solution and the good long-term result achieved should be helpful in the decision-making of similar cases.

Learning points

- In the case of a chronic wound with recurrent bleedings, consider Klippel-Trenaunay syndrome (KTS) as a potential underlying condition.

- Surgical or interventional treatments for KTS are often at high risk: primary amputation is a valuable option that could guarantee safety and an acceptable quality of life to the patient.

Contributors GP and LC were involved in the care of the patient. $\mathrm{MM}$ and GP wrote the manuscript. All the authors approved the final version. 


\section{Images in...}

Funding The authors have not declared a specific grant for this research from any funding agency in the public, commercial or not-for-profit sectors.

Competing interests None declared.

Patient consent for publication Obtained.

Provenance and peer review Not commissioned; externally peer reviewed.

\section{ORCID iDs}

Massimo Mattioli http://orcid.org/0000-0002-2118-7260
Gabriele Pagliariccio http://orcid.org/0000-0001-9946-4574

\section{REFERENCES}

1 John PR. Klippel-Trenaunay syndrome. Tech Vasc Interv Radiol 2019;22:100634.

2 Berchiolli R, Marconi M. Klippel-Trenaunay syndrome: a dramatic presentation. Eur J Vasc Endovasc Surg 2018:56:299.

3 Ishikawa K, Funayama E, Yamamoto Y, et al. Squamous cell carcinoma arising in a chronic leg ulcer in Klippel-Trenaunay syndrome after the Charles procedure: a case with 40 years of follow up. J Dermatol 2019;46:e403-5.

Copyright 2021 BMJ Publishing Group. All rights reserved. For permission to reuse any of this content visit

https://www.bmj.com/company/products-services/rights-and-licensing/permissions/

BMJ Case Report Fellows may re-use this article for personal use and teaching without any further permission.

Become a Fellow of BMJ Case Reports today and you can:

- Submit as many cases as you like

- Enjoy fast sympathetic peer review and rapid publication of accepted articles

- Access all the published articles

- Re-use any of the published material for personal use and teaching without further permission

\section{Customer Service}

If you have any further queries about your subscription, please contact our customer services team on +44 (0) 2071111105 or via email at support@bmj.com.

Visit casereports.bmj.com for more articles like this and to become a Fellow 